\title{
Serving the child A human rights approach to literacy and learning
}

\author{
Marian Koren \\ Head of Research \\ Netherlands Public Library Association \\ Netherlands
}

\begin{abstract}
School libraries have an excellent position to contribute to the development of skills of children, young people and teachers and educational staff to access sources for information and learning. Even if resources are limited, an active school librarian is an indispensable link between different parts of the whole school community. Therefore they need to work on their own literacy development. Applying human rights of children in the educational context of today means to respect their right to information, to have access to materials, to education, to values as human beings, as stated in the UN Convention on the Rights of the Child (1989). Rights of equal access to literacy services and social inclusion must also be applied in hybrid library environments. New tools in school library services developed in the Netherlands, include digital school library services, a reading and information literacy curriculum and promoting programmes. They help (young) people to participate in society and take responsibility for their own (learning) lives. IASL could partner with other international organisations and institutions, which work for equal rights and basic skills and services for children and young people.
\end{abstract}

\section{Literacy and learning}

The human capacity to learn has been the object of reflection, policy making and various practices. For what purpose is a human being learning, and for what purpose will his/her acquired learning be used? As soon as one person tells to another person what he or she should learn, something of the beautiful capacity will be lost. Learning is a case of freedom: it can only take place in a free atmosphere and environment; Learning pre-supposes an open mind, a preparedness to make efforts and to discover. Learning, discovering is a mission which is submitted to a human being at birth, a task which is sufficient to last for his whole life. In the end, it may result in that a human being has acquired a better understanding of himself and his environment, the world. Better understanding may contribute to a greater chance for peaceful existence.

These lines may summarise the ideas of international organisations which focus on the human capacity to learning and reflection as a major factor to improve human society. Human values, such as that every human being should be able to develop him/herself to the fullest potential and to use the individual talents, are central to these concepts. They are guaranteed in human rights.

A number of factors contributes to the greater importance of lifelong learning. Developments in science and technology, changes in industrial structures, changes in the organisation of labour and work; growing world population, the influence of television and other media, the focus on the individual, environmental issues, and globalisation are some of 
these factors. In other words: 'Today, biographies of individuals are less predetermined and are thus more open to change than ever before. Modern 'patchwork biographies' are the result of such openness. At the same time, the indeterminate character of life assigns burden on the individual to make decisions about what to do and how to live.' (UNESCO, 2001)

'Lifelong learning is most important, because we must give people conditions to exercise a right that is the right to know, to education, to culture throughout their life span. (Councillor, quoted in Calixto, 2001) The recognition of the individual right to education and learning, as formulated in the 20th century, makes clear that States must do their utmost to realise these rights for every individual. Most States also do understand the necessity of education for employment and economic growth.

\section{School libraries as literate environments}

What role does the school library play in the knowledge-based society? Does it pay special attention to the support and development of multi-literacies in the educational system? The literacy development of school librarians themselves is a prerequisite for serving children and young people in attractive learning environments.

In the international community, UNESCO as the lead agency and international coordinator of the United Nations Literacy Decade (2003-2012), states that 'literacy for all is at the heart of basic education for all ....[and] creating literate environments and societies is essential for achieving the goals of eradicating poverty, reducing child mortality, curbing population growth, achieving gender equality and ensuring sustainable development, peace and democracy.' The Decade is realized through programmes, particularly through the Literacy Initiative for Empowerment (LIFE) launched in October 2005 during the $33^{\text {rd }}$ session of UNESCO's General Conference, and more broadly, through the international coordination of Education for All (EFA). In its fourth Global Monitoring Report on Education for All, UNESCO clarifies the notion of 'literate' environments:

"The specific contents of literate environments vary from setting to setting. For example, in households, a stimulating literate environment would have an abundance of reading materials (e.g. books, magazines or newspapers) and/or communication and electronic media (e.g. radios, mobile phones, televisions and computers). In neighbourhoods and communities, a rich literate environment would have numerous signs, posters and handbills, as well as literacy-promoting institutions such as schools, offices, courts, libraries, banks and training centres. And yet literate environments are more than places offering access to printed matter, written records, visual materials or advanced technologies; ideally, they should enable the free exchange of information and provide an array of opportunities for lifelong learning. Indeed, whether they be in households, neighbourhoods, workplaces or communities, literate environments influence not only those directly exposed to them but also other members of the society.” (UNESCO, 2005, Chapter 8).

UNESCO stresses the role of literacy in achieving education for all (UNESCO, 2005): 'A good quality basic education equips pupils with literacy skills for life and further learning; literate parents are more likely to send their children to school; literate people are better able to access continuing education opportunities; and literate societies are better geared to meet pressing development challenges.' 
In international librarianship and library policies, 'lifelong literacy' has been adopted as a major advocacy goal. As IFLA's president Kay Raseroka stressed, we have to think of 'literacy' at large, of 'multi-literacies', in order to take into account all types of communities and cultural communication, including oral literacy. 'The concept of 'Lifelong Literacy' recognizes the impact of the speed of change and the penetration of new technologies and spheres of knowledge. It recognizes that users and librarians need to work at their ability to be information literate over a lifetime. It encompasses the sustained ability to acquire and use information as appropriate to any situation within and beyond the library, both locally and globally (Rader 1991). It involves an array of competencies appropriate for individuals and groups to survive and function successfully in an information continuum through the use of a variety of literacies, acquired as and when necessary. It covers all forms in which information is communicated and carried: visual, textual and sound and all forms by which human beings process information, including Braille, sign language and oral traditions as well as printed, electronic and other kinds of documentary records' (Raseroka, 2005a).

As all libraries, school libraries should play their part in the knowledge-based society and make their important role clear to policy makers and decision takers, within and outside the educational system. Literacy -creating and -sustaining activities, designed to encourage the use and development of literacy practices, may involve support for literacy through use of the media, books, multiple languages, information and communication technology (ICT), and cultural and library-based activities. People differ in their ways of learning and acquiring and processing information. Therefore, a multimedia approach to library services is a general international professional standard. For a long time, for example, library collections consisted for about $5 \%$ of audio-visual materials. Media related to music became popular in the library service and are a self-evident part of their collections.

The educational field appreciates the contribution of libraries to learning, but very often they only think of existing learning models of tutoring and tests. But there is more, libraries are familiar with a diversity of learning. Especially the contribution to unintentional learning is important: 'Public libraries are unique in the way that they can allow those tiny portions of learning to invisibly change people's lives’ (Batt,1998).

School libraries have a role to play in the synergy of intentional and unintentional learning for life. Various surveys demonstrate the influence of school libraries: school libraries form an important indication for the literate environments of schools, and the size of their collections indicates the availability of literacy resource where instruction takes place. In this way pupils are confronted with substantial differences of access to a school or classroom library, depending on geography: rural communities, small towns and large cities." In a recent Canadian survey, a similar relationship between the school's library and students' test scores was found. Students in schools with librarians were more likely to report that they enjoy reading. In those schools with trained library staff students were better in reading tests.

\section{Librarians as lifelong learning links}

School libraries have an excellent position to contribute to the development of skills of children, young people and teachers and educational staff to access sources for information and learning. The variety of sources nowadays available and the variety of skills required for teaching and learning programmes is a challenge, which could make the library into a multidimensional service organisation for literacy and learning. 
This, in theory, perfect role is in reality often limited due to a number of reasons, most of them well-known: limited resources, limited visibility of the library services, lack of recognition by teaching staff and management, poor professional education. This last element is one on which we can work ourselves as school librarians. Even if resources are limited, we can get involved in collaboration with teachers and in this way learn about their subjects, and the special skills required for thinking and working in their specific fields. Regardless of resources, we can participate in project teams, adding our specific library and information skills to the project aims, and in the meantime learning about the needs of teachers and pupils. In this way, an active school librarian becomes an indispensable link between different parts of the whole school community. Librarians are in a unique position to shape educational innovation. In order for librarians to emerge as leaders in the educational community, it is essential that careful attention be paid to current issues (Henri, 2004).

As IFLA stressed in its Presidential Theme, 'Libraries for Lifelong Literacy' , all literacies need to be developed and maintained throughout life, not only by information users, but also by librarians and other information workers. Librarians must therefore enhance their information literacy teaching abilities beyond that of basic user instruction to include new kinds of outreach activities, services and approaches to meet the needs of those with different and multiples literacies (Raseroka, 2005a).

Extending our own skills is not an end in itself, or simply aimed at improving our position as librarians in the educational system. In fact, the whole educational system is not an end in itself, but serves the child. There is a risk that in the turbulence of new technologies, new learning methods and updated school curricula, the literacy competences are too much technology/ society-driven. It is therefore adequate to refer to the UN Convention on the Rights of the Child, to keep a balanced perspective: the right of the child to develop him/herself to the fullest potential. Here lies the real challenge for school librarians: to have an eye for the potential of the child, and create an environment in which this potential may grow and unveil itself. Then, it may be appropriate to work with learnercentred curricula for various literacies as well.

\section{Human rights of children: information and education}

School library services are not a luxury, or only for the happy few but a consequence of applying human rights of children in the educational context of today. Their right to information, to have access to materials, to education, to values as human beings, as stated in the UN Convention on the Rights of the Child (1989), require equal access to literacy services and social inclusion. If we take the perspective of children and young people, we must acknowledge that in many countries children form a large part, up to half of the library users. Therefore their right of access to information, including information about rights, is important. Generally speaking about right to access and freedom of expression, these two rights are considered as being interrelated. The right to freedom of expression includes the right to have access to information. One can hardly form an opinion, discuss matters, write an article or make a news programme without sources of information. In fact, expressing one's views and opinions may create a new need for information or form a new source of information for another human being.

In the case of children, however, the right of access to information and the right to freedom of expression are not considered as having the same right-bearer, namely children, but are very often opposed to each other; the right to freedom of expression of adults and, 
because of the nature or effects of some of these expressions, children's limited right of access to information, as they also have the right to protection and should be protected from harmful information.

So, speaking about access and freedom of expression, we have to consider first of all the importance of freedom of expression of children themselves. An example of this in the political field is the declaration of children at the Belfast Euronet Symposium 1998: A Children's Agenda for Europe. ' We demand that the European Union listen carefully to the voices of its 90 million children and young people under 18 years of age. Twenty percent of Europe's children live in poverty - despite the countries of the European Union being among the richest in the world. Children's rights to protection from abuse, violence, crime, exploitation and pollution within the European Union are far from guaranteed. The development of the single market has brought some benefits but not enough has been done to make sure that children and young people's specific needs have been taken into account. We urge the politicians and policy makers of our Europe and countries to take action to promote and protect children's rights and treat us equally and with respect. ${ }^{1}$ Not every child will express herself in this way, but her opinion and view on matters of life, the school, the neighbourhood, the environment should be heard.

Almost all states in the world (and even the USA has at least signed the Convention) are parties to the Convention and have accepted its obligations; they are committed to implement the various articles and provisions of the Convention. The role and activities of schools and public libraries can be considered as part of this implementation of the Convention of making the right to have access to information and human rights education effective for the child. Therefore no state, school or public library can maintain that it has nothing to do with the Convention or with children's rights. In fact, nobody can refrain from being concerned with the human rights of children.

In article 17 of the Convention on the Rights of the Child we find the relationship between right of access to information and education, including human rights education confirmed.

\section{Article 17}

States Parties recognise the important function performed by the mass media and shall ensure that the child has access to information and material from a diversity of national and international sources, especially those aimed at the promotion of his or her social, spiritual and moral well being and physical and mental health. To this end, States Parties shall:

(a) Encourage the mass media to disseminate information and material of social and cultural benefit to the child and in accordance with the spirit of article 29;

(b) Encourage international co operation in the production, exchange and dissemination of such information and material from a diversity of cultural, national and international sources;

(c) Encourage the production and dissemination of children's books;

(d) Encourage the mass media to have particular regard to the linguistic needs of the child who belongs to a minority group or who is indigenous;

(e) Encourage the development of appropriate guidelines for the protection of the child from information and material injurious to his or her well being, bearing in mind the provisions of articles 13 and 18.

\footnotetext{
${ }^{1}$ Quoted in: Ruxton, S., A Children's Policy for 21st century Europe: First Steps, Euronet, Brussels, 1999, p. 3.
} 
Several aspects of article 17 refer to educational aims. (1) the qualification that information and material envisaged should be of social and cultural benefit to the child. (2) sources of information, especially those aimed at the social, spiritual, and moral well-being and physical and mental health. (3) the process of dissemination of information and material in accordance with the spirit of article 29, which also deals with the aims of education. (4) respecting the linguistic needs of the child. (5) A negative indication is given by the requirement that information should not be injurious to the child's well-being.

This paragraph focuses on the reference in article 17(a) to article 29 as this gives the strongest indication of the required provisions.

Article 29

1. States Parties agree that the education of the child shall be directed to:

(a) The development of the child's personality, talents and mental and physical abilities to their fullest potential;

(b) The development of respect for human rights and fundamental freedoms, and for the principles enshrined in the Charter of the United Nations;

(c) The development of respect for the child's parents, his or her own cultural identity, language and values, for the national values of the country in which the child is living; the country from which he or she may originate, and for civilisations different from his or her own;

(d) The preparation of the child for responsible life in a free society, in the spirit of understanding, peace, tolerance, equality of sexes, and friendship among all peoples, ethnic, national and religious groups and persons of indigenous origin;

(e) The development of respect for the natural environment.

2. No part of the present article or article 28 shall be construed so as to interfere with the liberty of individuals and bodies to establish and direct educational institutions, subject always to the observance of the principles set forth in paragraph 1 of the present article and to the requirements that the education given in such institutions shall conform to such minimum standards as may be laid down by the State.

The different elements in the aim of education reveal the catalogue of aspirations in the work within the United Nations with the Universal Declaration as its source. It should be noted that the development of the child's personality is the first aim mentioned. The formulation of development 'to their fullest potential' indicates that mainstream development with average results is insufficient. Attention has to be paid to the uniqueness of each child, which should be given all possibilities to develop. This also requires an individual approach, providing an inspiring environment and challenges for that particular child. The fullest potential of every human being in a spiritual sense is living as an authentic, true human being.

The development of respect for human rights and principles enshrined in the Charter of the United Nations is a consistent continuation of the first paragraph. No human development is possible without respect for others and acknowledging their dignity as human beings. Such respect has to be fostered by teaching human rights and by human rights education. It should be noted, that whatever programme or method of teaching human rights is used, it all boils down to the consciousness of the teacher and librarian and her/his awareness of human rights in human relationships and activities, at school and in the school library.

The reference to respect for the child's cultural identity, language and values is important as it implies that education stimulates the desire to become acquainted with one's cultural tradition. As such the aim is broader than a reference to linguistic needs or the needs 
of minority children. The second part of the provision shows that the aim of education can only be understood and achieved from a multicultural point of view. Such an approach will only succeed if educators are deeply interested in the riches of each culture and demonstrate the values found in these traditions.

The development of social participation is envisaged in the next paragraph on 'preparing the child for a responsible life in a free society'. The formulation reflects the former paradigm in which childhood was only seen as a preparation to adulthood. Nowadays the focus has changed: being a child, living through the period of childhood, has a value in itself. It might even be that in respect of human development, psychologically, this period should be valued more than the period of adulthood, which socially, is valued higher than childhood. The preparation for a responsible life is not aimed at using clichés and prejudices, earning a maximum of money or trying to beat others in bloody competition. Education should, on the contrary, take place in a spirit of understanding, peace, tolerance, equality of sexes and friendship among people from different beliefs, backgrounds and nations.

The Convention on the Rights of the Child gives a common basis for all working with children. Teachers, school and public librarians should use the formulations of various rights in their policy plans and activity programmes, set up with participation of the children and young people themselves. This will empower children and support their skills in a broader environment.

\section{Serving the child in hybrid library environments}

A human rights approach can also be applied in hybrid library environments and be helpful in closing the information gap. Many children are dependent on adults in their need for information and learning.

In the Netherlands, a number of new tools in school library services have been developed. Examples can be given of digital school library services for pupils, teachers and school librarians; of a reading literacy curriculum; of web based reading promotion programmes; services for reading materials in other languages; web based information literacy programme; digital information services for ethnic minorities, to mention a few. These tools are aimed at including people (young and old) of all walks of life, to be able to participate in society and take responsibility for their own (learning) lives.

\section{Reading promotion}

Public libraries have developed a number of reading promotion programmes. They are addressing individuals: babies, toddlers and their parents, young children and adolescents, the general public and elderly. In their approach they also pay attention to those who have reading difficulties, for one reason or another: physical, mental, social, educational etc. To give some examples from the Netherlands: A cooperative approach of libraries and reading promotion agencies has been developed since the seventies, resulting in professional programmes and partnerships. National reading promotion policy focuses on reading for pleasure, including all ages, and people with various backgrounds. Examples are: Children's Book Jury, National Reading Programme, National Reading Aloud Days, 50+ reading aloud, Reading Clubs etc. 
A number of programmes offered by public libraries are so attractive that schools also use them in their classes. Other programmes are addressing schools directly with a specific aim of reading for pleasure. There is a variety in short term, or incidental programmes. The educational field prefers structural programmes which cover all age groups. Therefore, the library association has developed a range of reading promotion activities which follow the curriculum in pre-school, primary and secondary education. This reading curriculum follows the stages of development of language and reading in the educational programmes, but gives it added value through materials, suggestions, tips and activities focusing on reading for pleasure, as distinct from the school-approach of reading as a technical skill.

A number of programmes, developed nationally, can be used by the local public library at any time, which fits in the local programme of activities and events. In this way, libraries make optimal use of their resources, and the resources available at national level. The programming teams at national level consist of a number of local librarians, bringing their expertise to the development of new programmes, supported and coordinated by the expertise and partnerships of the national Public Library Association.

Digital services as reading promotion. Increasingly, digital services and websites are developed by the library association, and used to encourage reading, both in a school setting and for pleasure. In recent years, ICT has been a good tool for offering reading promotion through dedicated websites and the library portal (www.bibliotheek.nl). The main website for reading promotion is the Reading Square (www.leesplein.nl). It provides materials and tips for children, young people and adults in an attractive setting which encourage reading for pleasure. A digital reference service, Al@din, offers possibilities to ask questions on all topics of interests. The queries from children and young people on this digital service delivered by one thousand of librarians are increasing. Some local libraries (Haarlem, Oss) have already set up forms of a digital children's library, which will be used for a national children's digital library. A research project will be connected to it, focussing on retrieval skills related to language and psychological development. Participation by children to give their views on books and to recommend them to others, are encouraged through a digital site called My Stamp (www.mijnstempel.nl). Peer-to-peer information on books might prove to be another helpful reading promotion tool, especially for less-skilled readers.

\section{Multimedia and media literacy}

In the exploration of including multimedia in learning processes, the Council for Education has also explored the educational role of the (public) broadcast. It advised, in the same way as there is an Educational expert centre for the Web (Kennisnet.nl) to create a Centre Education and Media. In general, the educational function of broadcasting organisations should be a clearly visible function and more integrated in the broadcasting structure. The Centre should focus on the added value by the media for learning. Broadcasting programmes should be more related to various learning paths within and outside the school programme. This offers opportunities to work with external partners and share knowledge and responsibilities. Libraries are, according to other research (Cultuurnet.nl) the most used partners for schools.

Among the successful programmes, the Council mentions are the Z@ppelin programmes for youth, which are placed in an educational context. Youth libraries cooperate with the programmes in which children's literature takes a prominent place. The reuse of broadcast material is a heavily studied subject, as this would give a boost to the multi-faceted character of learning. This has also been mentioned by the Council for Culture in its advice 
on Media wisdom, advanced forms of media literacy. In this advice the Council recommends a stronger role of public libraries in various forms of learning and literacy.

Some of the research on reading has also addressed the relation with multimedia. The results are useful for further improvement of learning and library services. Verhallen (2002) found that Turkish and Moroccan children of five years of age with retarded language development, learned much better from picture books fit for their age, when they were read to, supported by multimedia. Reading aloud has stronger learning effects when accompanied by sounds and animation for these children.

The Netherlands Public Library Association is active to take steps for programmes to improve information and media literacy parallel to reading literacy and reading for pleasure by making digital services interactive and peer-to-peer. These tools become valuable incentives to develop and maintain literacy as a skill and attitude which will help to be included in society and find one’s way through life.

\section{Virtual school library (www.schoolbieb.nl)}

A new challenge is to focus on target groups which have little or no reading experience at all: (functional ) illiterates. Very often this is also requiring a multicultural approach by the libraries. How to design these services is still in debate, but steps have been made to design a lifelong reading curriculum with adequate library services. The Ministry has launched an Action Plan to combat illiteracy and low literacy rates. (Van der Hoeven, 2005) Libraries are cooperating with schools, broadcasting organisations, immigrant groups and centres for adult education to provide adequate services. Dedicated websites for new immigrants and those willing to learn something new are created, and easily available in learning corners in public libraries.

Parallel to the development of the virtual library in the library portal:

www.bibliotheek.nl, libraries made connection to the educational field with the development of the virtual school library (www.schoolbieb.nl). A number of services supplied to primary and secondary education, are presented in digital form for three categories: pupils/students, teachers and school librarians. Appropriate media and content is presented according to the type and level of education. These sources for educational processes contain not only references to books or articles but also to video's and contain full text e-books and encyclopaedia articles. Teams of teachers and librarians are in charge of monitoring content and quality of sources. This virtual learning library is now extended to include materials and multimedia for adult education and literacy. In this way, learning processes are supported, regardless of whether they concern formal or non-formal education. Specific content for adult education is provided by the public library of Amsterdam.

In the same way as most young people are familiar with the Ask-a-Librarian service, Al@din, through the use of TV-adds, major campaigns to make the virtual school library known are launched. Campaigns focus each year on a new target group, related to new content for this group. Librarians from public libraries address school librarians in secondary education with presentations, demonstrations and a toolkit, containing a film, posters and promotional material. In order to address the pupils and students, a quiz around the virtual school library can be launched by the local partners. 


\section{International agenda and cooperation}

Human rights are a global framework and international point of reference for all political decision making. In this sense, IASL could partner with other international organisations and institutions, which work for equal rights and basic skills and services for children and young people. IFLA is useful partner in this respect: As IFLA's president Kay Raseroka stressed: 'The library is an institution respecting human rights, specifically as they relate to the right of access to information for all, especially for children and youth, who are vulnerable to information deprivation through deliberate actions by adults.' (Raseroka, 2005b) In the same way as IFLA, IRA (the International Reading Association) and IBBY (The International Board on Books for Young People) signed a memorandum of Understanding Raseroka, 2005c), IASL and IFLA could agree on a partnership for worldwide literacy through school libraries. They could support advocacy for literate societies.

As is stated in the nine Priorities for action of the UNESCO EFA Monitoring report:

"It is very clear that the EFA goals can be met only through the development of literate societies, in which all literate individuals have the means and the opportunity to benefit from rich and dynamic literate environments. Policies to develop rich literate environments alongside schooling and programmes that ensure that youth and adults become literate - are thus important. Such policies can include support for libraries, local-language newspapers, book publishing, access of adults to school libraries and radio listening groups." (p. 249)

This Action line may form the framework for respecting children's rights in the field of literacy and learning. A common agenda of IASL and IFLA could follow, with other partners, such as UNICEF. In the end it means, to actually serve the child, on the child's conditions. Children have more than a say in their own (learning) lives.

\section{References}

Batt, C., The engine of the community, in: Library - Technology. 5 (4) Aug 2000, p. 50.

Calixto, J-A., As bibliotecas públicas portuguesas face aos desafios da sociedade da informação. Portuguese public libraries facing the challenge of the information society, in: Liberpolis, Revista das Bibliotecas Publicas. (2) 1999, p. 3-7.

Calixto, J. A.,The educational roles of public libraries in Portugal. Political and professional perceptions, Thesis (Ph.D.)-University of Sheffield, Sheffield, 2001.

Guidelines for Library-based Literacy Programmes: some practical suggestions, IFLA Section on Reading, 2001. http://www.ifla.org/VII/s33/project/literacy.htm

Hoeven, M. van der, M. Rutte, M. van der Laan, Van A tot Z betrokken: aanvalsplan laaggeletterdheid 20062010, Ministerie van Onderwijs, Cultur en Wetenschap, SDU, Den Haag, 2005.

Holden, J., Creative Reading. Young people, reading and public libraries, Demos, London, 2004 (Creative Commons).

Henri, J., M. Asselin (eds,), Leadership issues in the information literate school community, Libraries Unlimited, London, 2005.

Kaegbein, P., B. Luckham, V. Stelmach (edited on behalf of IFLA Round Table on Research in Reading), Studies on Research in Reading and Libraries. Approaches and Results from Several Countries, K.G. Saur, Munchen etc., 1991. (Contributions to Library Theory and Library History, Vol. 3). 
Koren, M., Tell me! The right of the child to information, NBLC, The Hague, 1996.

Koren, M.(ed.), Wat vragen kinderen? Inlichtingenwerk in de jeugdbibliotheek, [What do children ask?] NBLC, Den Haag, 2003 (Bibliotheekverkenningen deel 3).

Lankvelt- van der Zee, Th. Van, Bibliotheekwerk voor ouderen en mensen met leesproblemen, [Library services for the elderly and people with reading difficulties], Vereniging van Openbare Bibliotheken, Den Haag, 2004 (Bibliotheekverkenningen deel 5).

Library Research Services, http://www.lrs.org/impact.asp

Lemmens, M. B. Vermeeren, Schoolbibliotheken en informatievaardigehden: een gesprek met James Henri, in: Bibliotheek \& Archiefgids, 2, 2006, p. 37-41.

Nannings, E., W. van der Pennen (eds.) Handboek Bibliotheekwerk voor 4-12 jarigen [Handbook Library services to 4-12 years olds,, NBLC/ Biblion, Den Haag, 2001 and updates

NBLC Organisatiehandleiding Bibliotheekwerk voor baby’s, peuters en kleuters, Biblion, en Haag, 1999. [Handbook Library services to baby's and toddlers]

OECD-Pisa Studies at: www.pisa.oecd.org/knowledge/home/intro.htm

Raseroka, K. (2005a). Libraries for Lifelong Literacies, IFLA Presidential Theme 2003-2005, http://www.ifla.org/III/gb/prtheme03-05.htm

Raseroka, K. (2005b): Bridges to Lifelong literacy. Keynote at $14^{\text {th }}$ European Conference on reading, Literacy without Boundaries, Zagreb, Croatia, July 31-August 3, 2005.

http://www.hcd.hr/conference/key_raseroka_eng.pdf

Raseroka.K. (2005c). A Memorandum of Understanding, signed in Zagreb with the presidents of the International Reading Association (IRA) and the International Board on Books for Children (IBBY).

School libraries and student achievement; a study by Queen’s University and People for Education, The Ontario Library Association, 2006, Toronto. www.peopleforeducation.com/reports/library/OLAstudy.pdf.

Tellegen, S., Why do children enjoy reading?, in: School libraries in view, 15, Autumn 2001, p. 14-18.

UNESCO Institute for Education, Hamburg, UNESCO Onderwijsdocumentatie: http://www.unesco.org/education/uie/documentation/index.shtml

UNESCO Learning. The Treasure Within. Report to UNESCO of the International Commission on Education for the Twenty-first Century. Over lifelong learning: http://www.unesco.org/education/index.shtml

UNESCO, Education for All, Literacy for Life. Forth Education For All Global Monitoring Report 2006,

UNESCO, Paris, 2005 : http://portal.unesco.org/education/en/ev.php-

URL_ID=43283\&URL_DO=DO_TOPIC\&URL_SECTION=201.html

Verhallen, M., Elektronische boeken in de vroegschoolse educatie, Stichting Lezen, 2002.

Voogd, L. de, Immigranten informeren. Lezen en tekstgebruik in meertalig perspectief, [immigrants inform themselves: Reading and use of text in multilingual perspective] NBLC, Den Haag, 2002 (Bibliotheekverkenningen deel 1).

Voorlezen voor ouderen (Samengesteld door PBC Noord-Brabant) [Reading aloud to the elderly], NBLC, Den Haag, 2002, (Bibliotheekverkenningen deel 2).

Wonderen, R. Van, S. Broersen en J. Scheeren: Leesbevordering 1992-2002: Evaluatie 10 jaar leesbevorderingsbeleid, Research voor Beleid, Leiden, 2003 (ISBN 90-9017568-7). 


\section{Dutch Websites}

Vereniging van Openbare Bibliotheken: www.debibliotheken.nl

Netherlands Public Library Association

Stichting Lezen: www.lezen.nl

Foundation Reading. It has also a database with research on reading.

CPNB: www.cpnb.nl

Collective Promotion for the Dutch Book: Book Promotion Cooperation of Group of General Publishers, The Booksellers Federation and the Netherlands Public Library Association

virtuele schoolbibliotheek www.schoolbieb.nl

Virtual school library

Leesplein www.leesplein.nl

Everything about books and reading and reading aloud for childen, young people and adults.

Boekenpret en Fantasia www.boekenpretfantasia.nl

Reading promotion projects on a structural longitudinal basis for children up till 12 years of age.

Mijnstempel.nl www.mijnstempel.nl

'My stamp': children can write their own review, which can be read and commented upon by others.

Kinderboekenweek www.kinderboekenweek.nl

Children's book week, organised by the CPNB, (book promotion organisation) with many activities by libraries.

Nederlandse Kinderjury www.kinderjury.nl

Children between 6 and 12 year of age chose their favourite title among the books poublished last year.

Jonge Jury www.jongejury.nl

Young Jury, young people between 12 and 16 years of age chose their favorite book from last year publications.

Databank Meertalig Materiaal www.meertalen.nl

Guide for media and materials suitable for children with another home language than Dutch

Jeugdbieb www.jeugdbieb.nl

Digital children’s library: Extensive number of Informative websites selected for children

De Leesmug www.leesmug.nl

The digital children's library of Haarlem City library

Makkelijk Lezen Plein www.makkelijklezenplein.nl

Site with easy-to-read materials.

Ik wil iets leren www.ikwilietsleren.nl/

I want to learn something. Portal on learning courses connected with library and reference service

\section{Author Note}

Marian Koren, Ph.D., is Head of Research and International Affairs for the Netherlands Public Library Association in The Hague, Netherlands. She works on innovative concepts and library strategies: www.debibliotheken.nl/english.

Marian Koren studied Dutch and international law; and studied Swedish with a focus on children's literature and culture. She received her Ph.D. cum laude from the University of Amsterdam for the study: "Tell Me! The Right of the Child to Information", relating to human rights of children and the right to information, with its implications for libraries. She writes and lectures internationally on these topics, including the United Nations Convention on the Rights of the Child.

Marian Koren was member (2001-2005) of the Professional Committee and Governing Board of the International Library Association, IFLA, and interim director for EBLIDA in 2006. 
Reproduced with permission of the copyright owner. Further reproduction prohibited without permission. 